\title{
HEAVY METAL CONTAMINATIONS AND HEALTH RISK ASSESSMENT FROM FRUITS AND VEGETABLES IN BANGALORE RURAL MARKETS, KARNATAKA, INDIA.
}

\author{
L. Shivakumar ${ }^{1}$, K. Ramakrishna Reddy ${ }^{2, *}$ and B.M.Kalshetty ${ }^{3}$ \\ ${ }^{1}$ Research \& Development Centre, Bharathiar University, Coimbatore- 641046, India. \\ ${ }^{2} \mathrm{P}$ G Department \& Research Studies in Chemistry, Government Science College (Autonomous), \\ Bengaluru-560001. India \\ ${ }^{3}$ Department of Chemistry, BLDE'S Science College, Jamkhandi, Bagalkot, Karnataka, India. \\ *E-mail: rkrchem@gmail.com
}

\begin{abstract}
The study is to assess heavy metals contamination in vegetables and fruits in Bangalore Rural taluk markets such as Nelamangala, Doddaballapura, Devanahalli and Hosakote. Samples randomly collected from these markets were analyzed for heavy metals, viz. Lead, Chromium, Cadmium, Arsenic, Mercury and Copper in vegetables like Tomato (Solanum lycopersicum), Brinjal (Solanum melongena), Radish (Raphanus sativus), Carrot (Daucus carota), Cauliflower (Brassica oleracea), Beans (Phaseolus vulgaris), Spinach (Spinacea oleracea), Banana (Musa paradisiaca), Mango (Mangifera indica) by using standard methods, such as ICP-MS. The Metal pollution index and Hazard quotient were calculated. The results indicate that the presence of heavy metals in vegetables and fruits was beyond the permissible limits of human consumption set by FAO/WHO. Consumption of contaminated fruits and vegetables may disturb biochemical and biological activities in human beings.
\end{abstract}

Keywords: Heavy Metals, Vegetables, Metal Pollution Index, Hazards Quotient and ICP-MS

(C) RASĀYAN. All rights reserved

\section{INTRODUCTION}

Though heavy metals are natural elements found in the earth's crust, the environmental pollution is due to anthropogenic activities, fertilizer and pesticide use in agricultural practices. ${ }^{1}$ Vegetable is a part of the common diet throughout the world, as they provide essential nutrients, antioxidants and metabolites and act as a buffer for acid substances during the digestion process. ${ }^{2}$ But with plants being good absorbers of metals from the soil, both essential and toxic elements were present in vegetables over a wide range of concentrations. ${ }^{3}$ The intake of contaminated vegetables may lead to many lingering diseases. For instance, continuous exposure to $\mathrm{Cd}$ can cause pulmonary effects like emphysema, bronchiolitis, and alveolitis. ${ }^{4}$ Industrial and agricultural drainage contains pesticides, fertilizers, effluents and runoff, in addition to sewage, which contaminates water bodies and deposits sediments with huge quantities of inorganic anions and heavy metals. ${ }^{5}$ The main sources of metal pollution from human activities are industrial, petroleum contamination and sewage disposal. An organic pollutant can undergo decomposition but heavy metals remain in the environment for a long time and impact the human health. In this study, heavy metals such as Lead, Cadmium, Copper, Mercury, Arsenic and Chromium were analyzed in samples collected in different market places of Nelamangala, Doddaballapura, Devanahalli and Hosakote taluks of Bangalore rural district. ${ }^{6}$ Intake of contaminated vegetables and fruits causes health risk. ${ }^{7}$ This study provides data on the levels of heavy metals in vegetables and fruits found in Bangalore rural markets, which would be a baseline data for further studies. ${ }^{8}$ The impact of metals present in vegetables and their hazards calculated. Since heavy metal contamination of food items is one of the most important aspects of food quality assurance, the present investigation focused on Metal Pollution Index (MPI), Average Daily Index (ADI), Hazard Quotient (HQ) and Hazard Index (HI) as an advanced part of the research work. ${ }^{9}$

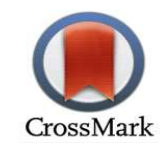


RASĀYAN J. Chem.

Vol. 13 | No. 4 |2498-2507| October - December | 2020

\section{Metal Pollution Index (MPI)}

The overall load of metals in each vegetable growing at each site was assessed by the metal pollution index. ${ }^{10}$ It is the geometric mean of the concentration of all metals in the sample.

$$
\operatorname{MPI}(\mathrm{mg} / \mathrm{kg})=\left(\mathrm{C}_{1} \times \mathrm{C}_{2} \mathrm{X} \mathrm{C}_{3} \ldots \ldots \mathrm{C}_{\mathrm{n}}\right)^{1 / \mathrm{n}}
$$

Where $C_{n}=$ Concentration of metal $n$ in the sample.

\section{Average Daily Index (ADI)}

Average Daily Index is a parameter to calculate how much amount of heavy metal intake by a person per day $(\mathrm{mg} / \mathrm{person} /$ day)

Mathematically it can be calculated by the given formula:

$$
\mathrm{ADI}=\mathrm{Cm} \times \mathrm{D} \text { intake } \mathrm{x} \mathrm{C} \text { Factor }
$$

Where,

$\mathrm{Cm}$ : Average heavy metal concentration of dry weight of the sample $(\mathrm{mg} / \mathrm{g})$

D intake: Daily intake vegetable (g/day). WHO guidelines suggest an average daily consumption of vegetables of 300 to $350 \mathrm{~g}$ per person. The mean of $325 \mathrm{~g} / \mathrm{person} /$ day was used in calculating the ADI values and the average weight of the person was taken as $60 \mathrm{~kg}$.

$\mathrm{C}$ factor: The conversion factor of 0.085 was used to convert fresh vegetable weight to dry weight.

\section{Hazard Quotient (HQ)}

Hazard quotient can be used to screen the level of risk associated with the consumption of contaminated food (USEPA). ${ }^{11}$ Hazard quotient is a proportion of the probable exposure to an element/chemical and level at which no negative impacts are expected. If $\mathrm{HQ}<1$, no potential health effects are expected from exposure, but if $\mathrm{HQ}>1$, there are potential health risks. ${ }^{12}$ Hazard quotient for adults and children associated with the intake of metals along with vegetables was assessed using the formula:

$\mathrm{HQ}=\mathrm{ADI} /(\mathrm{RfD})$

Where, ADI = Average daily intake of metal $(\mathrm{mg} / \mathrm{kg} /$ day $), \mathrm{RfD}=$ Reference oral dose of metal $(\mathrm{mg} / \mathrm{kg}$ of body weight/day).The oral reference dose for $\mathrm{As}, \mathrm{Cr}, \mathrm{Cu}, \mathrm{Pb}, \mathrm{Cd}$ and $\mathrm{Hg}$ reported was $0.0003,0.3,0.04$, $0.004,0.001,0.0001 \mathrm{mg} / \mathrm{kg} /$ day. $^{13}$

\section{Hazard Index (HI)}

Hazard Index (HI) was developed to evaluate the potential risk of more than one heavy metal to human health. HI is the sum of hazard quotients of all heavy metals, as mentioned in eq.4. It assumes that the magnitude of the adverse effect will be proportional to the sum of multiple metal exposures. It also assumes similar working mechanisms that linearly affect the target organ.

$$
\text { Hazard Index }(\mathrm{HI})=\Sigma \mathrm{HQ}=\mathrm{HQAs}+\mathrm{HQCr}+\mathrm{HQCu}+\mathrm{HQPb}+\mathrm{HQCd}+\mathrm{HQHg}
$$

If the HI $>1$, there is a concern for potential health effects. ${ }^{14}$ Though there was no apparent risk when each metal was analyzed individually, the risk could be higher when all metals are considered.

\section{EXPERIMENTAL}

\section{Study Area}

Bangalore rural district covers Nelamangala, Doddaballapura, Devanahalli and Hosakote taluks which are located at $12^{\circ} 15^{\prime}$ and $13^{\circ} 35^{\prime}$ North latitude $77^{\circ} 05^{\prime}$ and $78^{\circ} 0^{\prime}$ East and Longitude spread over 2259 sq. $\mathrm{km}$. The average annual rainfall is about $859.6 \mathrm{~mm}$ and temperature ranges between $15^{\circ} \mathrm{C}$ and $34^{\circ} \mathrm{C}$. Due to proximity to Bangalore city, there are a lot of industrial developments in this area. ${ }^{15}$

\section{Sampling Designs and Analysis}

Vegetable and fruit samples were collected for this study at different locations of Doddaballapura, Nelamangala, Devanahalli and Hosakote taluks separately in clean plastic zip-lock covers, labeled and 
RASĀYAN J. Chem.

Vol. 13 | No. 4 |2498-2507| October - December | 2020

brought to Laboratory for preparation. The samples were rinsed with double distilled water to remove dust, pollutants and fertilizers. Vegetable samples were cut into small pieces, air-dried for 2 days and dried at $100 \pm 1{ }^{\circ} \mathrm{C}$ in a hot air oven for 3 hours. ${ }^{16}$ Samples were then grounded in warm condition, passed through a sieve and then uniformly mixed. Composite samples were analyzed for Arsenic, Chromium, Copper, Lead, Cadmium and Mercury were carried out by standard methods, such as ICPMS (FSSAI Manual 2016 Method 3).

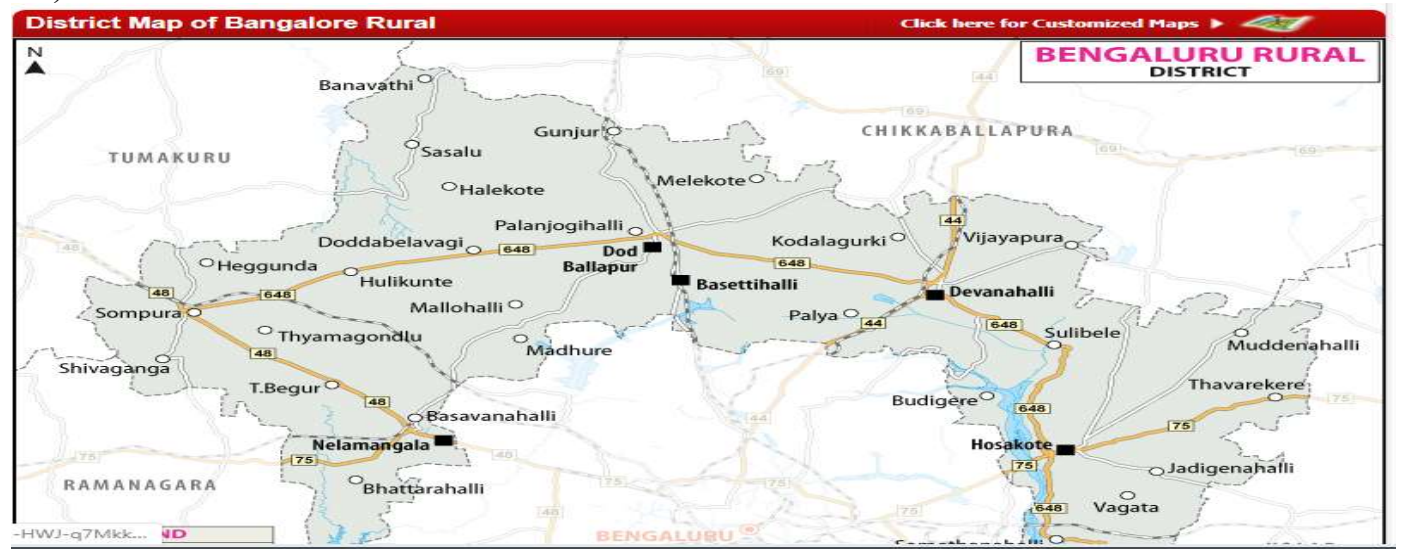

\section{Quality Control Analysis}

Fig.-1: Bangalore Rural District and Its Taluks

Prepared NIST grade heavy metal standard solution $(1000 \mathrm{mg} / \mathrm{L})$ namely. Arsenic, Chromium, Copper, Lead, Cadmium and Mercury. The standard curve plotted using various concentrations against sample solution and analyzed for metal content. In vegetable samples analyzed by using FSSAI Manual 2016 (Method 3).

\section{RESULTS AND DISCUSSION}

The results of heavy metals concentration and impact analysis parameters such as MPI, ADI, HQ and HI are summarized in Tables-1 to 13 and compared against corresponding established permissible limits. The Heavy Metals Standard legal limits reported for $\mathrm{Pb}, \mathrm{Cr}, \mathrm{Cd}, \mathrm{As}, \mathrm{Hg}$ and $\mathrm{Cu}$ in the vegetables were 0.2, $2.3,0.1,0.1,0.03$ and $40(\mathrm{mg} / \mathrm{kg})$ respectively. ${ }^{17}$

\begin{tabular}{c|c|c|c|c|c|c|c|c|c}
\hline \multicolumn{8}{c}{ Table-1: Heavy Metal Concentration of Vegetable in Nelamangala. } \\
\hline $\begin{array}{c}\text { Metals/ } \\
\text { Vegetables }\end{array}$ & Tomato & Brinjal & Radish & Carrot & $\begin{array}{c}\text { Cauli } \\
\text { Flower }\end{array}$ & Beans & Spinach & Banana & Mango \\
\hline $\mathrm{As}$ & 0.380 & 0.103 & BDL & 0.083 & 0.052 & BDL & 0.072 & BDL & 0.032 \\
\hline $\mathrm{Cr}$ & 6.203 & 3.034 & 4.148 & 3.634 & 4.143 & 1.543 & 4.813 & 0.913 & 0.153 \\
\hline $\mathrm{Cu}$ & 13.937 & 2.133 & 2.501 & 2.133 & 3.259 & 0.059 & 3.909 & 9.259 & 15.609 \\
\hline $\mathrm{Pb}$ & 1.780 & 1.202 & 1.124 & 0.702 & 2.502 & 0.042 & 1.801 & 0.502 & 29.201 \\
\hline $\mathrm{Cd}$ & 0.208 & 0.061 & BDL & 0.052 & 0.060 & 0.1560 & 0.020 & 0.810 & 0.050 \\
\hline $\mathrm{Hg}$ & BDL & 0.030 & 0.011 & 0.050 & 0.013 & 0.021 & 0.041 & BDL & 0.011 \\
\hline
\end{tabular}

\begin{tabular}{c|c|c|c|c|c|c|c|c|c}
\hline \multicolumn{8}{c}{ Table-2: Acceptable Daily Intake (ADI) of Vegetables in Nelamangala } \\
\hline Metals/DIR & Tomato & Brinjal & Radish & Carrot & Cauliflower & Beans & Spinach & Banana & Mango \\
\hline $\mathrm{As}$ & 0.1050 & 0.0285 & BDL & 0.0229 & 0.0144 & BDL & 0.0199 & BDL & 0.0088 \\
\hline $\mathrm{Cr}$ & 1.7136 & 0.8381 & 1.1459 & 1.0039 & 1.1445 & 0.4263 & 1.3296 & 0.2522 & 0.0423 \\
\hline $\mathrm{Cu}$ & 3.8501 & 0.5892 & 0.6909 & 0.5892 & 0.9003 & 0.0163 & 1.0799 & 2.5578 & 4.3120 \\
\hline $\mathrm{Pb}$ & 0.4917 & 0.3321 & 0.3105 & 0.1939 & 0.6912 & 0.0116 & 0.4975 & 0.1387 & 8.0668 \\
\hline $\mathrm{Cd}$ & 0.0575 & 0.0169 & BDL & 0.0144 & 0.0166 & 0.0431 & 0.0055 & 0.2238 & 0.0138 \\
\hline $\mathrm{Hg}$ & BDL & 0.0083 & 0.0030 & 0.0138 & 0.0036 & 0.0058 & 0.0113 & BDL & 0.0030 \\
\hline
\end{tabular}

Heavy metals concentration in nine vegetable and fruit samples consumed by all classes of Indian citizens were analyzed and results are summarised in Tables-1 to 13. The safe limit reported in vegetables for Arsenic, 
RASĀYAN J. Chem.

Vol. 13 | No. 4 |2498-2507| October - December | 2020

Chromium, Copper, Lead, Cadmium and Mercury are 0.1, 2.3, 40.0, 0.2, 0.1 and $0.03 \mathrm{mg} / \mathrm{kg}$ respectively. ${ }^{18}$ The arsenic concentration is higher than the safe limit in tomato and brinjal, but the other values are found to be within the safe limit in the vegetables at Nelamangala as shown in Table-1.

\begin{tabular}{c|c|c|c|c|c|c|c|c|c}
\hline \multicolumn{2}{c}{ Table-3: HQ and HI Values of vegetables in Nelamangala. } \\
\hline $\begin{array}{c}\text { Metals/DI } \\
\mathrm{R}\end{array}$ & Tomato & Brinjal & Radish & Carrot & $\begin{array}{c}\text { Cauli } \\
\text { Flower }\end{array}$ & Beans & Spinach & Banana & Mango \\
\hline $\mathrm{As}$ & 5.83 & 1.58 & BDL & 1.27 & 0.80 & BDL & 1.11 & BDL & 0.49 \\
\hline $\mathrm{Cr}$ & 0.10 & 0.05 & 0.06 & 0.06 & 0.06 & 0.02 & 0.07 & 0.01 & 0.00 \\
\hline $\mathrm{Cu}$ & 1.60 & 0.25 & 0.29 & 0.25 & 0.38 & 0.01 & 0.45 & 1.07 & 1.80 \\
\hline $\mathrm{Pb}$ & 2.05 & 1.38 & 1.29 & 0.81 & 2.88 & 0.05 & 2.07 & 0.58 & 33.61 \\
\hline $\mathrm{Cd}$ & 0.96 & 0.28 & $\mathrm{BDL}$ & 0.24 & 0.28 & 0.72 & 0.09 & 3.73 & 0.23 \\
\hline $\mathrm{Hg}$ & $\mathrm{BDL}$ & 1.38 & 0.51 & 2.30 & 0.60 & 0.97 & 1.89 & BDL & 0.51 \\
\hline $\begin{array}{l}\mathrm{Hazard} \\
\text { Index(HI) }\end{array}$ & 10.54 & 4.92 & 2.15 & 4.92 & 4.99 & 1.76 & 5.68 & 5.39 & 36.64 \\
\hline
\end{tabular}

\begin{tabular}{|c|c|c|c|c|c|c|c|c|c|}
\hline \multicolumn{10}{|c|}{ Table 4: Heavy Metal Concentration in Vegetables in Devanahalli } \\
\hline $\begin{array}{c}\text { Metals/ } \\
\text { vegetable } \\
\text { s } \\
\end{array}$ & Tomato & Brinjal & Radish & Carrot & $\begin{array}{l}\text { Cauli } \\
\text { Flower }\end{array}$ & Beans & Spinach & Banana & Mango \\
\hline As & 0.250 & 0.035 & BDL & BDL & 0.091 & 0.052 & 0.150 & BDL & 0.060 \\
\hline $\mathrm{Cr}$ & 4.613 & 3.113 & 2.253 & 0.063 & 3.213 & 1.153 & 3.113 & 0.083 & 0.251 \\
\hline $\mathrm{Cu}$ & 15.509 & 18.159 & 15.209 & 12.301 & 5.559 & 0.159 & 2.501 & 8.209 & 15.209 \\
\hline $\mathrm{Pb}$ & 1.122 & 1.902 & 3.501 & 4.202 & 6.502 & 0.091 & 4.222 & 0.801 & 31.202 \\
\hline $\mathrm{Cd}$ & 0.152 & 0.012 & 0.040 & 0.062 & 3.212 & BDL & 3.152 & 0.081 & 6.102 \\
\hline $\mathrm{Hg}$ & 0.112 & 0.021 & 0.014 & 0.042 & 0.112 & 0.024 & BDL & 0.011 & 0.082 \\
\hline
\end{tabular}

\begin{tabular}{c|c|c|c|c|c|c|c|c|c}
\hline \multicolumn{8}{c}{ Table-5: Acceptable Daily Intake (ADI) Vegetables in Devanahalli. } \\
\hline $\begin{array}{c}\text { Metals/ } \\
\text { DIR }\end{array}$ & Tomato & Brinjal & Radish & Carrot & $\begin{array}{c}\text { Cauli } \\
\text { Flower }\end{array}$ & Beans & Spinach & Banana & Mango \\
\hline $\mathrm{As}$ & 0.0691 & 0.0097 & BDL & BDL & 0.0251 & 0.0144 & 0.0414 & BDL & 0.0166 \\
\hline $\mathrm{Cr}$ & 1.2743 & 0.8600 & 0.6224 & 0.0174 & 0.8876 & 0.3185 & 0.8600 & 0.0229 & 0.0693 \\
\hline $\mathrm{Cu}$ & 4.2844 & 5.0164 & 4.2015 & 3.3982 & 1.5357 & 0.0439 & 0.6909 & 2.2677 & 4.2015 \\
\hline $\mathrm{Pb}$ & 0.3100 & 0.5254 & 0.9672 & 1.1608 & 1.7962 & 0.0251 & 1.1663 & 0.2213 & 8.6196 \\
\hline $\mathrm{Cd}$ & 0.0420 & 0.0033 & 0.0111 & 0.0171 & 0.8873 & BDL & 0.8707 & 0.0224 & 1.6857 \\
\hline $\mathrm{Hg}$ & 0.0309 & 0.0058 & 0.0039 & 0.0116 & 0.0309 & 0.0066 & BDL & 0.0030 & 0.0227 \\
\hline
\end{tabular}

\begin{tabular}{c|c|c|c|c|c|c|c|c|c}
\hline \multicolumn{8}{c}{ Table-6: HQ and HI Values of Vegetables in Devanahalli } \\
\hline $\begin{array}{c}\text { Metals/ } \\
\text { vegetables }\end{array}$ & Tomato & Brinjal & Radish & Carrot & $\begin{array}{c}\text { Cauli } \\
\text { Flower }\end{array}$ & Beans & Spinach & Banana & Mango \\
\hline $\mathrm{As}$ & 3.84 & 0.54 & BDL & BDL & 1.40 & 0.80 & 2.30 & BDL & 0.92 \\
\hline $\mathrm{Cr}$ & 0.07 & 0.05 & 0.03 & 0.00 & 0.05 & 0.02 & 0.05 & 0.00 & 0.00 \\
\hline $\mathrm{Cu}$ & 1.79 & 2.09 & 1.75 & 1.42 & 0.64 & 0.02 & 0.29 & 0.94 & 1.75 \\
\hline $\mathrm{Pb}$ & 1.29 & 2.19 & 4.03 & 4.84 & 7.48 & 0.10 & 4.86 & 0.92 & 35.91 \\
\hline $\mathrm{Cd}$ & 0.70 & 0.06 & 0.18 & 0.29 & 14.79 & BDL & 14.51 & 0.37 & 28.09 \\
\hline $\mathrm{Hg}$ & 5.16 & 0.97 & 0.64 & 1.93 & 5.16 & 1.11 & BDL & 0.51 & 3.78 \\
\hline $\begin{array}{c}\text { Hazard } \\
\text { Index(HI) }\end{array}$ & 12.84 & 5.89 & 6.64 & 8.47 & 29.52 & 2.04 & 22.01 & 2.75 & 70.46 \\
\hline
\end{tabular}

Table-7: Heavy Metal Concentration of Vegetables in Doddaballapura.

\begin{tabular}{c|c|c|c|c|c|c|c|c|c}
\hline $\begin{array}{c}\text { Param } \\
\text { eter }\end{array}$ & Tomato & Brinjal & Radish & Carrot & $\begin{array}{c}\text { Cauli } \\
\text { Flower }\end{array}$ & Beans & Spinach & Banana & Mango \\
\hline $\mathrm{As}$ & 0.120 & 0.292 & BDL & BDL & 0.020 & BDL & 0.710 & 0.022 & BDL \\
\hline $\mathrm{Cr}$ & 4.113 & 1.213 & 4.051 & 9.213 & 8.113 & 0.711 & 2.213 & 0.081 & 0.090 \\
\hline $\mathrm{Cu}$ & 10.209 & 18.509 & 6.501 & 3.109 & 6.509 & 5.201 & 6.909 & 9.201 & 11.210 \\
\hline
\end{tabular}


RASĀYAN J. Chem.

Vol. 13 | No. 4 |2498-2507| October - December | 2020

\begin{tabular}{c|c|c|c|c|c|c|c|c|c}
$\mathrm{Pb}$ & 1.512 & 8.201 & 3.622 & 2.812 & 7.301 & 0.150 & 5.212 & 2.550 & 42.202 \\
\hline $\mathrm{Cd}$ & 0.080 & 0.020 & 0.152 & 0.035 & 0.040 & 0.020 & 0.090 & 0.901 & 8.020 \\
\hline $\mathrm{Hg}$ & 0.025 & 3.314 & 2.102 & 1.019 & 0.195 & BDL & 0.080 & BDL & 0.142 \\
\hline
\end{tabular}

The content of metals, i.e., $\mathrm{Cr}, \mathrm{Zn}, \mathrm{Cd}$ and $\mathrm{Cu}$ in the tomato of the studied area was comparable with values reported in the city of Varanasi, India. ${ }^{19}$ Chromium concentration is found to be more than the safe limit in all vegetables and fruits, except in beans.

Even though Chromium is essential for human beings and animals for lipid and carbohydrate metabolism up to $200 \mu \mathrm{g} / \mathrm{day}$, breaching normal concentration levels leads to hepatitis, gastritis, ulcers and lung cancer. ${ }^{10}$ Copper is an essential micronutrient that functions as a biocatalyst, required for body pigmentation Copper concentration in all and vegetable were found to be within the safe limit. Lead concentration is higher than the safe limit in all vegetables and fruits, except beans. Accumulation of lead is mainly due to a large number of small scale industries, vehicular emissions, suspended road dust and diesel generator sets. Uptake of lead in plants is regulated by $\mathrm{pH}$, particle size and Cat-ion exchange capacity of soil as well as by root exudation and another Physico-chemical parameters. ${ }^{20} \mathrm{Cadmium}$ is a highly toxic, non-essential, heavy metal that has no role in the biological process of living organisms. Even at a lower concentration of $\mathrm{Cd}$ in the food chain could be harmful. Cadmium concentration was found to exceed the safe limit in Tomato, Beans and Banana. Usage of contaminated water for irrigation, fertilizers, sewage and compost can rapidly increase the $\mathrm{Cd}$ uptake into plant tissues. ${ }^{21}$ Mercury concentration exceeded the safe limit in brinjal, carrot and spinach. Mercury is found alarmingly higher concentrations in both tomato and cabbage samples. The $\mathrm{Cu}, \mathrm{Cd}$ and $\mathrm{Pb}$ contents observed in the Spinacea leaves of the studied area were comparable with the values reported in the leaves found in Bangalore, Delhi and Bangladesh regions. ${ }^{22}$

\begin{tabular}{c|l|l|l|l|l|l|l|l|l}
\hline \multicolumn{8}{c}{ Table-8: Acceptable Daily Intake (ADI) of Vegetables in Doddaballapura. } \\
\hline \multirow{2}{*}{ Metals/DIR } & Tomato & Brinjal & Radish & Carrot & $\begin{array}{l}\text { Cauli } \\
\text { Flower }\end{array}$ & Beans & Spinach & Banana & Mango \\
\hline $\mathrm{As}$ & 0.0332 & 0.0807 & BDL & BDL & 0.0055 & BDL & 0.1961 & 0.0061 & - \\
\hline $\mathrm{Cr}$ & 1.1362 & 0.3351 & 1.1191 & 2.5451 & 2.2412 & 0.1964 & 0.6113 & 0.0224 & 0.0249 \\
\hline $\mathrm{Cu}$ & 2.8202 & 5.1131 & 1.7959 & 0.8589 & 1.7981 & 1.4368 & 1.9086 & 2.5418 & 3.0968 \\
\hline $\mathrm{Pb}$ & 0.4177 & 2.2655 & 1.0006 & 0.7768 & 2.0169 & 0.0414 & 1.4398 & 0.7044 & 11.6583 \\
\hline $\mathrm{Cd}$ & 0.0221 & 0.0055 & 0.0420 & 0.0097 & 0.0111 & 0.0055 & 0.0249 & 0.2489 & 2.2155 \\
\hline $\mathrm{Hg}$ & 0.0069 & 0.9155 & 0.5807 & 0.2815 & 0.0539 & BDL & 0.0221 & BDL & 0.0392 \\
\hline
\end{tabular}

\begin{tabular}{c|l|l|l|l|l|l|l|l|l}
\hline \multicolumn{9}{c}{ Table-9: HQ and HI Values of Vegetables in Doddaballapura } \\
\hline \multirow{2}{*}{ Metals/DIR } & Tomato & Brinjal & Radish & Carrot & $\begin{array}{l}\text { Cauli } \\
\text { Flower }\end{array}$ & Beans & Spinach & Banana & Mango \\
\hline $\mathrm{As}$ & 1.84 & 4.48 & BDL & BDL & 0.31 & BDL & 10.90 & 0.34 & - \\
\hline $\mathrm{Cr}$ & 0.06 & 0.02 & 0.06 & 0.14 & 0.12 & 0.01 & 0.03 & 0.00 & 0.00 \\
\hline $\mathrm{Cu}$ & 1.18 & 2.13 & 0.75 & 0.36 & 0.75 & 0.60 & 0.80 & 1.06 & 1.29 \\
\hline $\mathrm{Pb}$ & 1.74 & 9.44 & 4.17 & 3.24 & 8.40 & 0.17 & 6.00 & 2.94 & 48.58 \\
\hline $\mathrm{Cd}$ & 0.37 & 0.09 & 0.70 & 0.16 & 0.18 & 0.09 & 0.41 & 4.15 & 36.93 \\
\hline $\mathrm{Hg}$ & 1.15 & 152.58 & 96.78 & 46.92 & 8.98 & BDL & 3.68 & BDL & 6.54 \\
\hline Hazard Index & 6.34 & 168.74 & 102.46 & 50.81 & 18.75 & 0.87 & 21.82 & 8.48 & 93.33 \\
\hline
\end{tabular}

From Table-4, in Devanahalli, it can be seen that Arsenic concentration exceeded the safe limit in Tomato and Spinach. Chromium concentration exceeded the safe limit in Tomato, Brinjal, Cauliflower, and Spinach, except in, Radish, Carrot, beans and Banana. Copper concentration in all the fruits and vegetable were within the safe limit. Lead concentration exceeded the safe limit in all vegetables and fruits except beans. Cadmium concentration exceeded the safe limit in Tomato, Cauliflower, Spinach and Mango. Mercury concentration exceeded the safe limit in Tomato, Carrot, Cauliflower and Mango. From Table-7, in Doddaballapura, it can be seen that Arsenic concentration was more than the safe limit in Tomato, Brinjal and Spinach. Chromium concentration exceeded the safe limit in Tomato, Radish, Carrot, Cauliflower and Spinach. Copper concentration in all fruits and vegetables sampled were within a safe limit. Lead concentration exceeded the safe limit in all vegetables and fruits, except beans. Cadmium 
RASĀYAN J. Chem.

Vol. 13 | No. 4 |2498-2507| October - December | 2020

concentration exceeded the safe limit in Radish, Banana and Mango. Mercury concentration exceeded the safe limit in Brinjal, Radish, Carrot, Cauliflower, Spinach and Mango. ${ }^{23}$ From Table-10, in Hosakote, it can be seen that Arsenic concentration was higher than the safe limit in Spinach. Chromium concentration exceeded the safe limit in Tomato, Radish, Carrot, Cauliflower, Spinach and in others, was in the safe limit. Copper concentration in all the fruits and vegetables was within a safe limit. Lead concentration was higher than the safe limit in all vegetables and fruits, except Beans. Cadmium concentration was exceeded the safe limit in Tomato, Brinjal, Cauliflower, Beans, Spinach and Mango. Mercury concentration exceeded the safe limit in Brinjal, Cauliflower and others were in the safe limit. The impacts of heavy metal contamination on vegetables and fruits were analyzed by using HQ and HI. ${ }^{24}$

\begin{tabular}{c|c|c|c|c|c|c|c|c|c}
\hline \multicolumn{8}{c}{ Table-10: Heavy Metal Concentration of Vegetables in Hosakote } \\
\hline $\begin{array}{c}\text { Metals/ } \\
\text { DIR }\end{array}$ & Tomato & Brinjal & Radish & Carrot & $\begin{array}{c}\text { Cauli } \\
\text { Flower }\end{array}$ & Beans & Spinach & Banana & Mango \\
\hline $\mathrm{As}$ & 0.032 & 0.041 & 0.080 & 0.060 & 0.052 & BDL & 0.580 & 0.030 & BDL \\
\hline $\mathrm{Cr}$ & 2.513 & 1.916 & 4.210 & 3.183 & 5.215 & 0.150 & 3.213 & 0.050 & 0.901 \\
\hline $\mathrm{Cu}$ & 3.521 & 13.521 & 9.519 & 5.809 & 14.501 & 3.519 & 3.219 & 10.529 & 13.419 \\
\hline $\mathrm{Pb}$ & 2.201 & 5.925 & 6.502 & 3.901 & 7.525 & 0.082 & 9.701 & 7.582 & 25.501 \\
\hline $\mathrm{Cd}$ & 0.900 & 0.622 & 0.021 & 0.092 & 1.902 & 0.291 & 0.212 & 0.041 & 9.512 \\
\hline $\mathrm{Hg}$ & $\mathrm{BDL}$ & 0.032 & 0.012 & 0.011 & 0.132 & BDL & 0.011 & BDL & 0.081 \\
\hline
\end{tabular}

\begin{tabular}{c|l|l|l|l|l|l|l|l|l}
\hline \multicolumn{10}{c}{ Table 11: Acceptable Daily Intake (ADI) of Vegetables in Hosakote } \\
\hline Metals/DIR & Tomato & Brinjal & Radish & Carrot & Cauli flower & Beans & Spinach & Banana & Mango \\
\hline $\mathrm{As}$ & 0.0088 & 0.0113 & 0.0221 & 0.0166 & 0.0144 & BDL & 0.1602 & 0.0083 & BDL \\
\hline $\mathrm{Cr}$ & 0.6942 & 0.5293 & 1.1630 & 0.8793 & 1.4406 & 0.0414 & 0.8876 & 0.0138 & 0.2489 \\
\hline $\mathrm{Cu}$ & 0.9727 & 3.7352 & 2.6296 & 1.6047 & 4.0059 & 0.9721 & 0.8892 & 2.9086 & 3.7070 \\
\hline $\mathrm{Pb}$ & 0.6080 & 1.6368 & 1.7962 & 1.0777 & 2.0788 & 0.0227 & 2.6799 & 2.0945 & 7.0447 \\
\hline $\mathrm{Cd}$ & 0.2486 & 0.1718 & 0.0058 & 0.0254 & 0.5254 & 0.0804 & 0.0586 & 0.0113 & 2.6277 \\
\hline $\mathrm{Hg}$ & BDL & 0.0088 & 0.0033 & 0.0030 & 0.0365 & BDL & 0.0030 & BDL & 0.0224 \\
\hline
\end{tabular}

\begin{tabular}{c|c|c|c|c|c|c|c|c|c}
\hline \multicolumn{9}{c}{ Table-12: HQ and HI Values of Vegetables in Hosakote. } \\
\hline $\begin{array}{c}\text { Metals/ } \\
\text { DIR }\end{array}$ & Tomato & Brinjal & Radish & Carrot & $\begin{array}{c}\text { Cauli } \\
\text { flower }\end{array}$ & Beans & Spinach & Banana & Mango \\
\hline $\mathrm{As}$ & 0.49 & 0.63 & 1.23 & 0.92 & 0.80 & BDL & 8.90 & 0.46 & BDL \\
\hline $\mathrm{Cr}$ & 0.04 & 0.03 & 0.06 & 0.05 & 0.08 & 0.00 & 0.05 & 0.00 & 0.01 \\
\hline $\mathrm{Cu}$ & 0.41 & 1.56 & 1.10 & 0.67 & 1.67 & 0.41 & 0.37 & 1.21 & 1.54 \\
\hline $\mathrm{Pb}$ & 2.53 & 6.82 & 7.48 & 4.49 & 8.66 & 0.09 & 11.17 & 8.73 & 29.35 \\
\hline $\mathrm{Cd}$ & 4.14 & 2.86 & 0.10 & 0.42 & 8.76 & 1.34 & 0.98 & 0.19 & 43.79 \\
\hline $\mathrm{Hg}$ & $\mathrm{BDL}$ & 1.47 & 0.55 & 0.51 & 6.08 & BDL & 0.51 & BDL & 3.73 \\
\hline Hazard Index & 7.61 & 13.37 & 10.52 & 7.06 & 26.04 & 1.84 & 21.97 & 10.59 & 78.44 \\
\hline
\end{tabular}

\begin{tabular}{l|l|l|l|l|l|l|l|l|l|l}
\hline \multicolumn{10}{c}{ Table-13: Metal Pollution Index (MPI) for Vegetables in Bangalore Rural } \\
\hline Site/Vegetables & Tomato & Brinjal & Radish & Carrot & Cauli flower & Beans & Spinach & Banana & Mango \\
\hline Nelamangala & 1.65 & 0.34 & 0.6 & 0.32 & 0.33 & 0.17 & 0.35 & 1.36 & 0.33 \\
\hline Devanahalli & 0.84 & 0.31 & 0.58 & 0.39 & 1.25 & 0.12 & 1.73 & 0.22 & 1.24 \\
\hline Doddaballapura & 0.5 & 1.24 & 1.98 & 1.23 & 0.63 & 0.32 & 0.86 & 0.52 & 2.17 \\
\hline Hosakote & 0.89 & 0.71 & 0.42 & 0.4 & 1.4 & 0.34 & 0.72 & 0.35 & 2.99 \\
\hline
\end{tabular}

Graphical representation of Metal pollution index for Vegetables and fruits are as follows:

\section{Hazard Quotient (HQ)}

The HQ values of all heavy metal were compared in all the vegetables and fruits. If the observed value of HQ $>1$, causes more potential health effects. ${ }^{11,15}$ 
RASĀYAN J. Chem.

Vol. 13 | No. 4 |2498-2507| October - December | 2020

In Nelamangala Table-3, HQ value is higher than the safe limit for Arsenic in Tomato (5.83)>Brinjal (1.58) $>$ Carrot (1.27) for Copper in Mango (1.80)>Tomato (1.60), for Lead in Mango (33.61) > Cauliflower (2.88) $>$ Spinach (2.07) > Tomato (2.05) > Brinjal (1.38) > Raddish (1.29), for Cadmium in Banana (3.73), for Mercury in Carrot (2.30) $>$ Spinach(1.89) $>\operatorname{Brinjal(1.38)~.~}$

In Devanahalli Table-6, HQ value is higher for Arsenic in Tomato (3.84) $>$ Spinach (2.30) $>$ Cauliflower (1.40), for Copper in Brinjal (2.09) > Tomato (1.79) $>$ Mango and Raddish (1.75) $>$ Carrot (1.42), for Lead in Mango (35.91) $>$ Cauliflower (7.48) $>$ spinach (4.86) $>\operatorname{Carrot}(4.84)>\operatorname{Raddish}(4.03)>\operatorname{Brinjal}(2.19)>$ Tomato (1.29), for Cadmium in Mango (28.09) > Cauliflower (14.79), for Mercury in Tomato and Cauliflower (5.16) > Mango (3.78) > Carrot (1.93).

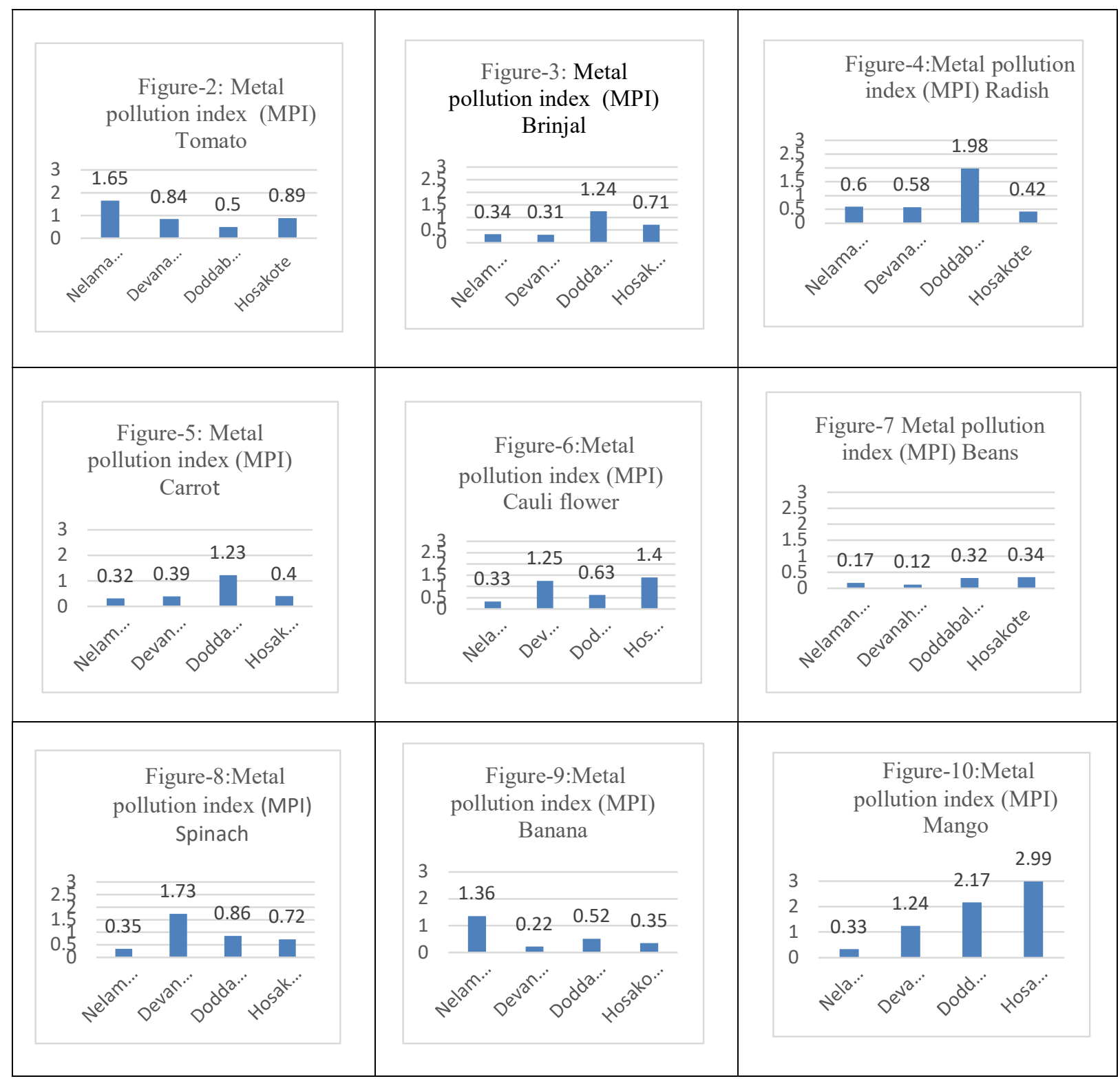

In Doddaballapura Table-9, HQ value is higher than the safe limit for Arsenic in Arsenic (10.90) $>$ Brinjal (4.48) > Tomato (1.18), for Copper in Brinjal (2.13) > Banana (1.06) > Tomato (1.18), for Lead in Mango $(48.58)>$ Brinjal $(9.44)>$ Cauliflower $(8.40)>$ spinach $(6.00)>$ Raddish $(4.17)>$ Carrot $(3.24)>$ Tomato (1.74), for Cadmium in Mango (36.93), Banana (4.15), for Mercury in Brinjal (152.58), Raddish(96.78) > Carrot (46.92) > Cauliflower (8.98), Mango (6.54), Spinach (3.68) > Brinjal (1.38) and Tomato(1.15). 
RASĀYAN J. Chem.

Vol. 13 | No. 4 |2498-2507| October - December | 2020

In Hosakote Table-12, HQ value is higher than the safe limit for Arsenic in Spinach (8.90) > Raddish (1.23) $>$ Carrot (1.27), for Copper in Mango (1.54) > Cauliflower (1.67), Brinjal (1.56), Raddish (1.10), for Lead in Mango (29.35) > Spinach (11.17) $>$ Banana (8.73) > Cauliflower (8.66) > Raddish (7.48) > Brinjal (6.82) $>$ Tomato(2.53), for Cadmium in Mango (43.79) $>$ Cauliflower (8.76) $>$ Banana (3.73) $>$ Brinjal (1.47), Mercury in Cauliflower(6.08) > Mango (3.73) > Brinjal (1.47).

Similar results were observed in Spinach for heavy metals ( $\mathrm{HQ}>500) \mathrm{As}, \mathrm{Mn}, \mathrm{Cu}, \mathrm{Cd}, \mathrm{Pb}$ and $\mathrm{Hg}$ content[24].

It shows from the HQ value that, most of the vegetables and fruits are higher than the safe in Bangalore Rural.

\section{Hazard Index (HI)}

The results from the Table-3, Nelamangala Market showed that the highest HI value found in Mango (36.64) $>$ Tomato (10.54) $>$ Spinach (5.68) $>$ Banana (5.39) $>$ Cauliflower (4.99) $>$ Carrot (4.92) $=$ Brinjal (4.92) > Radish (2.15) > Beans (1.76).

From the Table-6, it is observed that, HI exceeds the in Devanahalli market, Mango (70.46) $>$ Cauliflower (29.52) $>$ Spinach (22.01) $>$ Tomato (12.84) $>$ Carrot (8.47) $>$ Radish (6.64) $>$ Brinjal5.89) $>$ Banana (2.75) $>$ Beans (2.04).

The results from the Table-9, Doddaballapura Market, shows that, highest HI value found in Brinjal (168.7) $>$ Radish (102.5) > Mango (93.3) > Carrot (50.81) > Spinach (21.81) > Cauliflower (18.8) > Banana (8.48) $>$ Tomato (6.3) > Beans (0.87).

The results from the Table-12, Hosakote Market, shows that, highest HI value found in Mango (78.4) $>$ Cauliflower (26.04) $>$ Spinach (21.97) > Brinjal (13.37) > Banana (10.59) > Radish10.52) $>$ Tomato (7.61) $>$ Carrot (7.06) > Beans (1.84).

If the HI values exceeds 1.0, there is a concern for potential health effects. ${ }^{25}$ From the observed values, the maximum health effects is found in Mango and less in Beans.

\section{Metal Pollution Index (MPI)}

The MPI for lead, chromium, cadmium, arsenic, mercury and copper for vegetables and fruits is found to be several folds higher MPI ( $>1.0)$ as shown in Table-13. MPI values higher for Tomato (1.65), Banana (1.36) in Nelamangala, Cauliflower (1.25) and Mango (1.24) in Devanahalli, Mango (2.17), Raddish (1.98) and Brinjal (1.24) in Doddaballapura, Radish (2.99) in Hosakote. ${ }^{26}$ If the MPI values exceed 1.0, there is a concern for potential health effects.

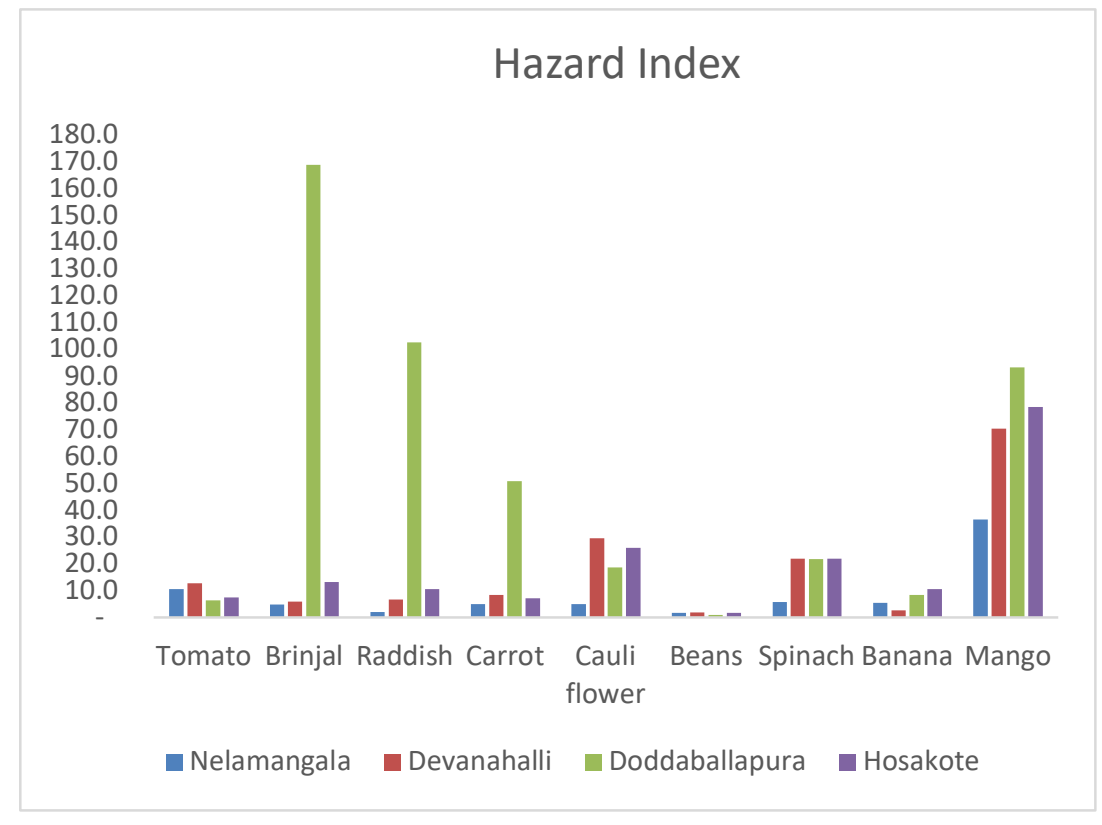

Fig.-11: Graphical Presentation of Hazard Index of Vegetables and Fruits 2505 


\section{CONCLUSION}

Experimental results for both vegetables and fruits were from the Average daily intake (ADI), Hazard Quotient (HQ), Hazard Index (HI) and Metal pollution index (MPI) showed that, consumption of vegetables and fruits may cause carcinogenic health risks to humans, due to high concentration of heavy metals such as Arsenic, Chromium, Copper, Lead, Cadmium and Mercury. After investigations, because of the health risk to the people of Bangalore Rural District., we recommend that awareness be created by Administrative Authorities and Public Health Department.

\section{ACKNOWLEDGEMENT}

The authors greatly acknowledge Vision group on Science and Technology (VGST), Government of Karnataka for providing K-FIST $\left(\mathrm{L}_{1}\right)$ grants to the PG Department of Chemistry and UGC for UGC-CPE / MRP grants to Government Science College (Autonomous), Bengaluru.

\section{REFERENCES}

1. P.K. Gautam, R.K. Gautam, S. Banerjee, M.C. Chattopadhyaya, J.D. Pandey,2016, Heavy Metals in the Environment: Fate, Transport, Toxicity and Remediation Technologies, Heavy Metals: Sources, Toxicity and Remediation Techniques, Nova Science Publishers, Inc., New York, pp101-130

2. M.K. Hasan, A. Shahriar, K.U. Jim, , Heliyon, 5,130(2019), DOI:10.1016/j.heliyon.2019.e02145

3. F.R. Galvan, V. Barranco, J.C. Galvan, Intech, 13(2016), DOI:10.5772/57353

4. S. Sharma, A. Bhattacharya, Applied Water Science, 7, 1067(2017), DOI:10.1007/s13201-016-0455-7

5. S. Naidoo, A.O. Olaniran, International Journal of Environmental Research and. Public Health, 11, 270(2013), DOI: 10.3390/ijerph110100249

6. M.M. Onakpa, A.A. Njan, O.C. Kalu, Annals Global Health, 84, 494(2018), DOI:10.29024/aogh.2314

7. P.B. Tchounwou, C.G. Yedjou, A.K. Patlolla, D.J. Sutton, Molecular Clinical Environmental. Toxicology, 101(2012), DOI:10.1007/978-3-7643-8340-4

8. N. Gurukiran, B.N. Kumara, M. Rafi, P.G. T, L. Sripathy, Mendely, 13,18(2017)

9. G. Mausi, G. Simiyu, S. Lutta, Journal of Environvironmental Earth Science, 4,8(2014)

10. A. Sharma, J.K. Katnoria, A.K. Nagpal, Springerplus, 5, 16(2016), DOI:10.1186/s40064-016-2129-1

11. G. Qingjie, D. Jun, X. Yunchuan, W. Qingfei, Y. Liqiang, Journal of China University of Geoscience, 19, 241(2008), DOI: 10.1016/S1002-0705(08)60042-4

12. F.M. Adebiyi, O.T. Ore, I.O. Ogunjimi, Heliyon, 6(2020), DOI:10.1016/j.heliyon.2019.e03092

13. A.A. Mohammadi, A. Zarei, S. Majidi, A. Ghaderpoury, Y. Hashempour, M.H. Saghi, A. Alinejad, M. Yousefi, N. Hosseingholizadeh, M. Ghaderpoori, Iran, MethodsX, 6, 1651(2019), DOI: 10.1016/j.mex.2019.07.017

14. M. Sultana, M. Mondol, A. Mahir, R. Sultana, S. Elahi, N. Afrose, A. Chamon, Bangladesh Journal of Scientifica and Industrial Research, 54 ,366(2019), DOI:10.3329/bjsir.v54i4.44570

15. N. Saha, M.R. Zaman, Environmental Monitoring and Assessesment, 185, 3878(2013), DOI: $10.1007 / \mathrm{s} 10661-012-2835-2$

16. A. Vella, E. Attard, Cosmetics, 6(2019), DOI:10.3390/COSMETICS6020028

17. H.M. Aghamirlou, M. Khadem, A. Rahmani, M. Sadeghian, A.H. Mahvi, A. Akbarzadeh, S. Nazmara, Journal of Environmental. Health Science and Engineering, 13, 8(2015), DOI:10.1186/s40201-0150189-8

18. F. Azi, M.O. Odo, P.A. Okorie, H.A. Njoku, V.N. Nwobasi, E. David, T.C. Onu, Food Science \& Nutrition, 6, 1544(2018), DOI:10.1002/fsn3.739

19. B.V. Tangahu, S.R. Sheikh Abdullah, H. Basri, M. Idris, N. Anuar, M. Mukhlisin, International Journal of Chemical Engineering, 11, 2011(2011), DOI:10.1155/2011/939161

20. M.A. Elbagermi, H.G.M. Edwards, A.I. Alajtal, ISRN Analytical Chemistry, 5, 2012(2012), DOI: $10.5402 / 2012 / 827645$

21. O.P. Sobukola, O.M. Adeniran, A.A. Odedairo, O.E. Kajihausa, African Journal of Food Science, 4, $393(2010)$

22. M. Jaishankar, T. Tseten, N. Anbalagan, B.B. Mathew, K.N. Beeregowda, Interdisciplinary. Toxicology, 7, 72(2014), DOI:10.2478/intox-2014-0009 
RASĀYAN J. Chem.

Vol. 13 | No. 4 |2498-2507| October - December | 2020

23. R.A. Kusumadewi, A. Wijayanti, R. Hadisoebroto, International Journal of Science \& Technology. Research, 8 (2019)

24. D. Jonathan, Journal of Environmental Science Toxicology And Food Technology, 6, 93(2013), DOI: $10.9790 / 2402-0638693$

25. E. Devanesan, M. Suresh Gandhi, M. Selvapandiyan, G. Senthilkumar, R. Ravisankar, Beni-Suef University Journal of Basic and Applied Sciences, 6, 292(2017), DOI:10.1016/j.bjbas.2017.04.011

26. R. Bhardwaj, A. Gupta, J.K. Garg, Water Science, 31, 66(2017), DOI:10.1016/j.wsj.2017.02.002

[RJC-6039/2020] 